\title{
The Pawpaw Research Program at the Horticulture Department of the University of Florence
}

\author{
Elvio Bellini, ${ }^{1}$ Stefania Nin, ${ }^{2}$ and Maurizio Cocchi $^{3}$
}

\begin{abstract}
Additional INDEX wORDS. Asimina triloba, breeding, cultivars, selections, varietal characterization, in vitro culture

Summary. The Horticulture Department of the University of Florence has been studying the pawpaw (Asimina triloba) since 1990 through collaboration with Italian fruit grower Domenico Montanari, who currently hosts the largest pawpaw orchard and variety collection in Italy. Research efforts are focused mainly on the development of new varieties and selections with desirable ornamental characteristics. New variety selection is based on high tree productivity, large fruit size, good organoleptic quality and improved fruit postharvest handling. The breeding program has resulted in 3,000 seedlings that are currently being evaluated in Tuscany, Italy. In addition to breeding efforts, 15 commercially available varieties were evaluated in replicated trials in 2000 and 2001, with selections characterized for vegetative, reproductive and pomological traits. In 2000 and 2001, the varieties 'Prima 1216' and 'Prolific' had high yields and should be suitable for production in Italian fruit-growing areas. Experiments to establish explants of pawpaw in culture were also performed testing a range of genotypes, disinfestation procedures, and methods to induce callus culture. Protocols for the propagation of pawpaw in vitro would offer many advantages for mass multiplication of desirable plants; however, the propagation of pawpaw in vitro has so far been met with limited success.
\end{abstract}

$\mathbf{T}$

he north american pawpaw is receiving increasing attention for its potential as a landscape tree, fruit crop, and as a source of important secondary products with anti-tumor and pesticidal properties (Bellini and Montanari, 1992a, 2000; Layne, 1996; McLaughlin, 1997; Pomper et al. 1999). Due to attractive tree form and fall color, as well as cold hardiness for the Italian climate, pawpaws are suitable for ornamental and biodiversification efforts in parks and gardens in Italy. Furthermore, the species has a very low susceptibility to pests and disease (Peterson, 1991) and produces fruit with a unique flavor and a high nutrient content (Peterson et al., 1982), thus also representing an alternative to traditional fruit crops for organic fruit production (Bellini and Montanari, 1992a, 2000).

In Italy, experimentation with pawpaw began in 1983 in Faenza, Italy at the farm of Domenico Montanari, which now hosts the largest Italian pawpaw orchard and collection. Initially, Montanari evaluated a range of American varieties under Italian climatic conditions (Bellini and Montanari, 1992b).

Breeding and selection efforts were initiated with the development of a seedling population of more than 1,000 individuals obtained from seed coming from the U.S., from open pollination of the variety 'Sunflower', and from a number of seedling selections.

\footnotetext{
Department of Horticulture, Florence University, 50019 Sesto Fiorentino (FI), Italy.

${ }^{1}$ Professor of pomology and fruit tree science, author to whom reprint request should be addressed; e-mail: elvio.bellini@unifi.it.

${ }^{2}$ Grant researcher.

${ }^{3}$ Undergraduate student. 
One selection, 'Montanari 1216' (now named 'Prima 1216'), had displayed cold hardiness, self-compatibility, and very large fruit size; a patent is currently pending on that selection (Bellini and Montanari, 2000).

\section{Breeding Program at the Horticulture Department of the University of Florence}

Our collaboration with Domenico Montanari began in the early 1990s and is still in progress, with a primary focus on the development of new pawpaw varieties and evaluation of commercially available varieties for suitability for Italian fruit-growing areas. Traits that will be selected for are high productivity, large fruit size, good organoleptic quality, improved fruit storability and resistance to post harvest handling. Storage and handling represent significant obstacles to the development of a large-scale commercial production of pawpaws. Also, interesting genotypes having double aptitude in ornamental value and fruit production will be identified.

Parents used in the breeding program were chosen within the first seedling population on the basis of agronomic, biological and pomological characteristics. In 1992, seed was obtained from a number of open pollinated isolated genotypes, and more than 2,800 seedlings were produced. A separate, parallel study was conducted with a wider genetic pool, to study the distribution of the progenies in relation to their respective female parents. In this study, 20 parental genotypes were selected on the basis of pomological traits, such as fruit shape (round to oval), size, homogeneity of both fruit shape and size within the tree and flowering form. From this work a total number of 430 seedlings were obtained. A seedling orchard was established in autumn 1995, after plantlets had been transplanted twice in containers of increasing size. These 2-year-old seedlings were planted out at the experimental farm Monna Giovannella at the University of Florence, in a slightly sloping field of about 2 ha ( 4.9 acres) and have been left unpruned. The seedlings are still in the juvenile phase, and are currently being evaluated for tree growth habit and vigor. Upon fruiting, seedlings will be selected based on fruit characteristics, ripening season, storage quality, as well as for yield and year-to-year consistency. We expect these trials to provide valuable information and genetic material for future work in pawpaw genetic improvement at the University of Florence.

\section{Characterization of some pawpaw varieties cultivated in Italy}

An evaluation of 15 pawpaw varieties commercially available in Italy was performed to examine adaptability of these varieties to the Italian climate. An orchard was established in 1990 in an experimental orchard located at Faenza, Italy with planting distances of $4.5 \times$
$2 \mathrm{~m}(14.76 \times 6.6 \mathrm{ft})$. Three replicate trees were planted for each variety. The pawpaw accessions included 14 varieties of American origin ('Sunflower', 'Overleese', 'Davis', 'Prolific', 'Sweet Alice', 'Maryfoos Johnson's', 'Mango', 'Taytwo', 'Taylor', 'Rebecca's Gold', 'NCl', 'Ithaca', 'Wells' and 'Wilson') and one of Italian origin ('Prima 1216'). Vegetative, reproductive and pomological characteristics were evaluated during the 2000 and 2001 seasons. Traits recorded for the vegetative characterization of trees included height and volumetric index of trees. Reproductive records included flowering time, ripening time, fruit weight, fruit soluble solids content, and finally tree yield. Data were analyzed by analysis of variance and means separation was performed by Duncan's multiple range test.

Analysis of variance showed a high variability among the varieties for many of the characters examined. There were significant differences among varieties in tree height and tree volumetric growth, with the variety Ithaca having the greatest height measurements both in 2000 and 2001 (Tables 1 and 2). In terms of flowering, there were significant differences among varieties in bloom time, with the varieties 'Overleese', 'Ithaca', 'Mango', and 'Sunflower' having the earliest bloom period in 2000 and 2001. The varieties Prima 1216, 'Sunflower' and 'Davis' bore the largest fruit [average weight of 202,216 , and $246 \mathrm{~g}(7.1$, 7.6 , and $8.7 \mathrm{oz})$, respectively] in both

Table 1. Vegetative and reproductive characteristics of 15 pawpaw varieties evaluated in 2000 in Faenza, Italy.

\begin{tabular}{|c|c|c|c|c|c|c|c|}
\hline Variety & $\begin{array}{c}\text { Tree } \\
\text { ht } \\
(\mathrm{cm})^{\mathrm{z}}\end{array}$ & $\begin{array}{c}\text { Tree } \\
\text { volumetric } \\
\text { index }^{\mathrm{y}}\end{array}$ & $\begin{array}{c}\text { Flowering } \\
\text { time } \\
(\mathrm{d})^{\mathrm{x}}\end{array}$ & $\begin{array}{c}\text { Ripening } \\
\text { time } \\
(d)^{v}\end{array}$ & $\begin{array}{c}\text { Fruit } \\
\text { wt } \\
(\mathrm{g})^{\mathrm{w}}\end{array}$ & $\begin{array}{c}\text { Soluble } \\
\text { solids } \\
(\%)\end{array}$ & $\begin{array}{c}\text { Tree } \\
\text { yield } \\
(\mathrm{kg})\end{array}$ \\
\hline Davis & $290.0 \mathrm{bc}$ & $1.15 \mathrm{~b}$ & $110 \mathrm{bc}$ & $248 \mathrm{bcd}$ & $216.3 \mathrm{a}$ & $21.6 \mathrm{cef}$ & $3.96 \mathrm{cde}$ \\
\hline Ithaca & $440.0 \mathrm{a}$ & $1.60 \mathrm{ab}$ & $106 \mathrm{~cd}$ & $252 \mathrm{ab}$ & $123.9 \mathrm{de}$ & $24.2 \mathrm{abc}$ & $10.08 \mathrm{~b}$ \\
\hline Mango & $415.5 \mathrm{ab}$ & $1.78 \mathrm{ab}$ & $106 \mathrm{~cd}$ & 246 cde & $196.1 \mathrm{abc}$ & $24.8 \mathrm{ab}$ & $10.73 \mathrm{~b}$ \\
\hline Maryfoos Johnson & $258.6 \mathrm{c}$ & $1.83 \mathrm{ab}$ & $110 \mathrm{bc}$ & $253 \mathrm{ab}$ & $198.0 \mathrm{ab}$ & $22.3 \mathrm{bcd}$ & $2.24 \mathrm{de}$ \\
\hline NC-1 & $385.0 \mathrm{ab}$ & $1.55 \mathrm{ab}$ & $112 \mathrm{~b}$ & $251 \mathrm{abc}$ & $164.6 \mathrm{abcd}$ & $24.9 \mathrm{ab}$ & $7.54 \mathrm{bc}$ \\
\hline Overleese & $360.0 \mathrm{abc}$ & $1.39 \mathrm{ab}$ & $104 \mathrm{~d}$ & $242 \mathrm{e}$ & $138.3 \mathrm{bcd}$ & $20.7 \mathrm{de}$ & 4.35 cde \\
\hline Prima 1216 & $382.0 \mathrm{ab}$ & $1.41 \mathrm{ab}$ & $110 \mathrm{bc}$ & $250 \mathrm{abc}$ & $209.5 \mathrm{a}$ & $18.9 \mathrm{e}$ & $15.70 \mathrm{a}$ \\
\hline Prolific & $310.0 \mathrm{bc}$ & $1.77 \mathrm{ab}$ & $112 \mathrm{~b}$ & $255 \mathrm{a}$ & $113.5 \mathrm{de}$ & $24.9 \mathrm{ab}$ & $11.22 \mathrm{~b}$ \\
\hline Rebecca's Gold & $330.5 \mathrm{abc}$ & $1.20 \mathrm{~b}$ & $116 \mathrm{a}$ & 246 cde & $64.9 \mathrm{e}$ & $21.4 \mathrm{cde}$ & $2.46 \mathrm{de}$ \\
\hline Sunflower & $320.0 \mathrm{bc}$ & $1.18 \mathrm{~b}$ & $106 \mathrm{~cd}$ & $250 \mathrm{abc}$ & $152.0 \mathrm{abcd}$ & $20.6 \mathrm{de}$ & $6.59 \mathrm{bcd}$ \\
\hline Sweet Alice & $250.0 \mathrm{c}$ & $1.36 \mathrm{ab}$ & $108 \mathrm{bcd}$ & $253 \mathrm{ab}$ & $173.9 \mathrm{abcd}$ & $21.2 \mathrm{cde}$ & $1.71 \mathrm{e}$ \\
\hline Taylor & $383.0 \mathrm{ab}$ & $1.74 \mathrm{ab}$ & $111 \mathrm{~b}$ & $252 \mathrm{ab}$ & $106.2 \mathrm{de}$ & $22.0 \mathrm{bcde}$ & $3.96 \mathrm{cde}$ \\
\hline Taytwo & $380.0 \mathrm{ab}$ & $1.56 \mathrm{ab}$ & $116 a$ & $244 \mathrm{de}$ & $127.2 \mathrm{cde}$ & $26.5 \mathrm{a}$ & $0.81 \mathrm{e}$ \\
\hline Wells & $257.0 \mathrm{c}$ & $1.97 \mathrm{a}$ & $109 \mathrm{bc}$ & --- & & --- & --- \\
\hline Wilson & $370.0 \mathrm{abcd}$ & $1.51 \mathrm{ab}$ & $111 \mathrm{~b}$ & 246 cde & $102.7 \mathrm{de}$ & $19.9 \mathrm{de}$ & $7.46 \mathrm{~b}$ \\
\hline$P^{\imath}$ & 0.0000 & 0.0070 & 0.0000 & 0.0002 & 0.0000 & 0.0000 & 0.0000 \\
\hline
\end{tabular}

${ }^{2}$ Based on three replicate trees for each variety; trees were planted in $1990 ; 1.0 \mathrm{~cm}=0.39$ inches; $1.00 \mathrm{~kg}=2.205 \mathrm{lb} ; 1 \mathrm{~g}=0.035 \mathrm{oz}$.

Tree volumetric index was calculated by $2 \mathrm{H} /$ longitudinal $\mathrm{D}+$ transversal $\mathrm{D}$; where $\mathrm{H}=$ maximum crown height, longitudinally and transversally, $\mathrm{D}=$ longitudinal and transversal crown diameter measured at the maximum extent

xFlowering time was evaluated at the peak of bloom judged by visual observation and expressed in days from 1 Jan.

"Ripening time was expressed in days from 1 Jan.

wFruit weight based on the weights of 20 fruit.

"Data were analyzed by analysis of variance and means separation was performed by Duncan's multiple range test with a $P<0.05$. 
Table 2. Vegetative and reproductive characteristics of 15 pawpaw varieties evaluated in 2001 in Faenza, Italy.

\begin{tabular}{|c|c|c|c|c|c|c|c|}
\hline Variety & $\begin{array}{c}\text { Tree } \\
\text { ht } \\
(\mathrm{cm})^{\mathrm{z}}\end{array}$ & $\begin{array}{c}\text { Tree } \\
\text { volumetric } \\
\text { index }^{y}\end{array}$ & $\begin{array}{l}\text { Flowering } \\
\text { time } \\
(\mathrm{d})^{\mathrm{x}}\end{array}$ & $\begin{array}{c}\text { Ripening } \\
\text { time } \\
(\mathrm{d})^{\mathrm{v}}\end{array}$ & $\begin{array}{c}\text { Fruit } \\
\text { wt } \\
(\mathrm{g})^{\mathrm{w}}\end{array}$ & $\begin{array}{c}\text { Soluble } \\
\text { solids } \\
(\%)\end{array}$ & $\begin{array}{l}\text { Tree } \\
\text { yield } \\
(\mathrm{kg})\end{array}$ \\
\hline Davis & $310.0 \mathrm{~cd}$ & $1.16 \mathrm{bc}$ & $97 \mathrm{bc}$ & $248 \mathrm{bcd}$ & $277.0 \mathrm{ab}$ & $19.4 \mathrm{ef}$ & 6.24 bcde \\
\hline Ithaca & $455.0 \mathrm{a}$ & $1.67 \mathrm{abc}$ & $92 \mathrm{~d}$ & $252 \mathrm{ab}$ & $134.4 \mathrm{~cd}$ & $19.8 \mathrm{def}$ & $11.35 \mathrm{ab}$ \\
\hline Mango & $430.0 \mathrm{ab}$ & $1.77 \mathrm{ab}$ & $92 \mathrm{~d}$ & $246 \mathrm{cde}$ & $170.8 \mathrm{bc}$ & $18.8 \mathrm{f}$ & $8.02 b c$ \\
\hline Maryfoos Johnson & $270.0 \mathrm{~d}$ & $1.55 \mathrm{abc}$ & $98 \mathrm{~b}$ & $253 \mathrm{ab}$ & $165.8 \mathrm{c}$ & $22.7 \mathrm{ab}$ & $1.66 \mathrm{de}$ \\
\hline NC-1 & $395.0 \mathrm{abc}$ & $1.57 \mathrm{abc}$ & $99 \mathrm{ab}$ & $251 \mathrm{abc}$ & $191.2 \mathrm{abc}$ & $22.8 \mathrm{ab}$ & $8.60 \mathrm{~b}$ \\
\hline Overleese & $366.7 \mathrm{abcd}$ & $1.48 \mathrm{abc}$ & $91 \mathrm{~d}$ & $242 \mathrm{e}$ & $206.8 \mathrm{abc}$ & $19.7 \mathrm{def}$ & 6.68 bcde \\
\hline Prima 1216 & $395.0 \mathrm{abc}$ & $1.44 \mathrm{bc}$ & $96 \mathrm{bc}$ & $250 a b c$ & $195.0 \mathrm{abc}$ & $19.2 \mathrm{ef}$ & $14.37 \mathrm{a}$ \\
\hline Prolific & $330.0 \mathrm{bcd}$ & $1.78 \mathrm{ab}$ & $97 \mathrm{bc}$ & $255 \mathrm{a}$ & $148.9 \mathrm{~cd}$ & $21.5 \mathrm{bc}$ & $14.30 \mathrm{a}$ \\
\hline Rebecca's Gold & $351.7 \mathrm{abcd}$ & $1.23 \mathrm{bc}$ & $102 \mathrm{a}$ & 246 cde & $62.4 \mathrm{~d}$ & $24.0 \mathrm{a}$ & 2.34 cde \\
\hline Sunflower & $331.7 \mathrm{bcd}$ & $1.08 \mathrm{c}$ & $92 \mathrm{~d}$ & $250 \mathrm{abc}$ & $280.8 \mathrm{a}$ & $22.3 \mathrm{~b}$ & $11.98 \mathrm{ab}$ \\
\hline Sweet Alice & $256.7 \mathrm{~d}$ & $1.35 \mathrm{bc}$ & $94 \mathrm{~cd}$ & $253 \mathrm{ab}$ & $191.0 \mathrm{abc}$ & $20.5 \mathrm{cde}$ & $1.91 \mathrm{de}$ \\
\hline Taylor & $393.3 \mathrm{abc}$ & $1.75 \mathrm{ab}$ & $97 \mathrm{bc}$ & $252 \mathrm{ab}$ & $174.8 \mathrm{abc}$ & $24.0 \mathrm{a}$ & 6.36 bcde \\
\hline Taytwo & $390.0 \mathrm{abc}$ & $1.58 \mathrm{abc}$ & $102 \mathrm{a}$ & 244 de & $197.3 \mathrm{abc}$ & $21.4 \mathrm{bcd}$ & $1.26 \mathrm{e}$ \\
\hline Wells & $283.3 \mathrm{~cd}$ & $2.11 \mathrm{a}$ & $94 \mathrm{~cd}$ & --- & -- & --- & --- \\
\hline Wilson & $370.0 \mathrm{abcd}$ & $1.52 \mathrm{abc}$ & $97 \mathrm{bc}$ & $246 \mathrm{cde}$ & $97.2 \mathrm{~cd}$ & $20.1 \mathrm{cdef}$ & $7.11 \mathrm{bcd}$ \\
\hline$P^{1}$ & 0.0050 & 0.0190 & 0.0000 & 0.0005 & 0.0000 & 0.0000 & 0.0000 \\
\hline
\end{tabular}

${ }^{2}$ Based on three replicate trees for each variety; trees were planted in $1990 ; 1 \mathrm{~cm}=0.39$ inches; $1.00 \mathrm{~kg}=2.205 \mathrm{lb}$.

Tree volumetric index was calculated by $2 \mathrm{H}$ / longitudinal $\mathrm{D}+$ transversal $\mathrm{D}$; where $\mathrm{H}=$ maximum crown height, longitudinally and transversally, $\mathrm{D}=$ longitudinal and transversal crown diameter measured at the maximum extent.

xFlowering time was evaluated at the peak of bloom judged by visual observation and expressed in days from 1 Jan.

"Ripening time was expressed in days from 1 Jan.

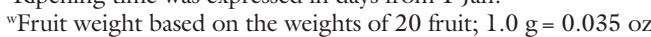

"Data were analyzed by analysis of variance and means separation was performed by Duncan's multiple range test with a $P<0.05$

2000 and 2001, while 'Rebecca's Gold' produced the smallest fruit $(64 \mathrm{~g})(2.3$ $\mathrm{oz})$. Fruit soluble solids range from 19 to $26.5 \%$ soluble solids in the varieties examined in both 2000 and 2001 . Tree yield was greatest for the variety Prima 1216 in 2000 and for the varieties Prima 1216 and Prolific in 2001.

\section{In vitro culture}

Vegetative propagation of pawpaw by conventional methods is difficult and micropropagation would be an alternative method for the production of many uniform plants of a selected superior genotype. Treatments were employed using various concentrations of sodium hypochlorite to disinfest explants to be used for callus induction. Quiescent buds and internodes were collected from 10-year-old trees of the varieties 'Davis', 'Sunflower', 'Overleese', 'Prima 1216', and 'Prolific' that were grown at the experimental farm of Domenico Montanari at Faenza, Italy. Explants were washed under tap water and then subjected to five disinfestation treatments consisting ofimmersion for 2 or $5 \mathrm{~min}$ in $1.0 \%, 2.0 \%, 2.5 \%, 3.5 \%$, and $5.0 \%$ sodium hypochlorite. All treated explants were rinsed two times with sterile distilled water and then placed in petri dishes containing $10 \mathrm{~mL}(0.34$ $\mathrm{fl} \mathrm{oz}$ ) of MS basal medium (Murashige and Skoog, 1962) supplemented with $2 \%$ sucrose and enriched with zeatine ( 5 $\mu \mathrm{M})$, only in the case of internodes. Two different solidification agents were used with or without $0.3 \%$ activated charcoal, $0.7 \%$ Difco-Bacto agar (Sigma-Aldrich Chemie Gmbh, Munich, Germany), and $0.3 \%$ Gelgrow (ICN Biomedicals Inc., Irvine, Calif.). The $\mathrm{pH}$ of the medium was adjusted to $5.8 \pm 0.1$ with $0.1 \mathrm{~N}$ sodium hydroxide before autoclaving. Cultures were incubated at $25^{\circ} \mathrm{C}\left(77.0^{\circ} \mathrm{F}\right)$ under a photoperiod of $16 \mathrm{~h}$ light (cool white fluorescent lamps, $\left.35 \mu \mathrm{mol} \cdot \mathrm{m}^{-2} \cdot \mathrm{s}^{-1}\right)$ and 8 h dark. Cultures ( 15 explants per treatment) were subcultured every $20 \mathrm{~d}$.

Most cultures were contaminated with fungal and bacterial organisms, which appeared on the medium surface within a few days. Explants that were free of microbial growth were found only with the buds of variety 'Davis' that were disinfested with $5 \%$ sodium hypochlorite for $2 \mathrm{~min}$. Induction of callus on the 'Davis' explants began $15 \mathrm{~d}$ after being placed on the medium where Gelgrow had been added, but that contained no activated charcoal. Callus occurred directly at the cut surface of the explants. However, explants that produced callus exhibited browning and did not survive after the second subculture. The few cultures that had viable callus exhibited poor growth. Alternative surface disinfestation treatments with various chemical agents, concentrations and times, as well as alternative explant sources are currently being examined with the hope of increasing the number of aseptic explants.

In conclusion, over 3,000 pawpaw seedlings are under long-term evaluation for fruit appearance, production, quality, postharvest handling, as well as tree ornamental potential for Italy and the Mediterranean region. Evaluation of commercially available varieties has already identified selections that perform well in the region of Emilia Romagna (e.g., 'sel. 938', 'sel. 1047', and 'sel. 1068'). Protocols for the propagation of pawpaw in vitro would offer many advantages for mass multiplication of desirable plants; however, the propagation of pawpaw in vitro has so far been met with limited success.

\section{Literature cited}

Bellini, E. and D. Montanari. 1992a. La coltura dell'Asimina triloba annonacea per i climi temperati. L'Informatore Agrario 38:59-72.

Bellini, E. and D. Montanari. 1992b. La coltura dell'Asimina in Italia. Esperienze maturate a Faenza. L'Informatore Agrario 45:51-64.

Bellini, E. and D. Montanari. 2000. Asimina triloba una realtà per la frutticoltura amatoriale italiana. Frutticoltura 1:54-61.

Layne, D.R. 1996. The pawpaw [Asimina triloba (L.) Dunal.]: A new fruit crop for Kentucky and the United States. HortScience 31:777-784.

McLaughlin, J.L. 1997. Anticancer and pesticidal components of pawpaw (Asimina triloba). Annu. Rpt. N Nut Growers Assn. 88:97-106.

Murashige, T. and F. Skoog. 1962. A revised medium for rapid growth and bioassay with tobacco tissue cultures. Physiol. Plant.51:473-497.

Peterson, RN. J.P. Cherry and J.G. Simmons, 1982. Composition of pawpaw (Asimina triloba) fruit. Annu. Rpt. N. Nut Growers Assn. 73:97-106.

Peterson, R.N. 1991 Pawpaw (Asimina). Acta Hort. 290:567-600.

Pomper, KW, D R Layne, and R N. Peterson 1999 The pawpaw regional variety trial, p. 353-357. In: J. Janick (ed.). Perspectives on new crops and new uses. ASHS Press, Alex., Va. 